\title{
Distribution and Abundance of Baling Twine in the Landscape Near Osprey (Pandion haliaetus) Nests: Implications for Nestling Entanglement
}

\author{
ReneE SeAcor ${ }^{1}$, KayHan Ostovar ${ }^{1}$, and Marco Restani ${ }^{2,3}$ \\ ${ }^{1}$ Environmental Sciences Program, Rocky Mountain College, 1511 Poly Drive, Billings, Montana 59102 USA \\ ${ }^{2}$ Department of Biological Sciences, St. Cloud State University, St. Cloud, Minnesota 56301 USA \\ ${ }^{3}$ Corresponding author: restani@stcloudstate.edu
}

Seacor, Renee, Kayhan Ostovar, and Marco Restani. 2014. Distribution and abundance of baling twine in the landscape near Osprey (Pandion haliaetus) nests: implications for nestling entanglement. Canadian Field-Naturalist 128(2): $173-178$.

Polypropylene baling twine used by Ospreys (Pandion haliaetus) during nest construction creates a risk of entanglement for nestlings and adults on the Yellowstone River, Montana. In 2013, we evaluated the abundance of twine in 2-km-radius buffer zones centred on 38 nests for three categories of road density. We found more twine per kilometre along roads in low $(n=19)$ and moderate $(n=13)$ road density nest buffer zones than in high road density nest buffer zones $(n=6)$. The estimated total amount of twine found along roads in nest buffer zones ranged from 0 to $2602 \mathrm{~m}$ and did not differ among road density strata. The percentage of Osprey nests containing twine was highest in low $(63.2 \%)$ and moderate $(61.5 \%)$ road density nest buffer zones and lowest (33.3\%) in high road density buffer zones, which reflected a gradient from rural and suburban to urban landscapes. The estimated total amount of twine within a nest buffer zone did not predict whether a nest contained twine. The amount of twine found in seven nests destroyed by wind or power company personnel ranged from 0 to $206 \mathrm{~m}$ and was not correlated with the amount of twine found in their buffer zones. During the 2012 and 2013 breeding seasons, four of 120 nestlings $(3.3 \%)$ became entangled in twine: two were cut free and fledged normally, one died, and one was euthanized. The abundance of twine in the environment surrounding nests and its slow rate of biodegradation mean that vigilance by citizen scientist nest monitors and assistance from power companies are the only short-term solution to reducing mortality resulting from entanglement.

Key Words: baling twine; entanglement; Montana; mortality; Osprey; Pandion haliaetus; Yellowstone River

\section{Introduction}

Many bird species incorporate atypical materials into their nests (Hansell 2000). A variety of species use anthropogenic nesting materials, such as plastic trash, twine, and rope, and the prevalence of plastics in nests is thought to be increasing (Montevecchi 1991; Antczak et al. 2010; Votier et al. 2011). Because plastics degrade slowly, using the percentage of nests containing plastics as an index of their abundance in the environment over time requires both a constant search effort and knowledge of bird population trends (Ryan et al. 2009). Moreover, the presence of plastics in large, long-lasting nests suggests that such an index is best considered over decades rather than years (Bond et al. 2012). Although some individuals within a species benefit by signaling conspecifics through the use of artificial nesting materials (Hansell 2000), plastic rope and twine present a potential risk of nestling and adult entanglement. In fact, mortality associated with the use of these nesting materials is well documented in White Storks (Ciconia ciconia; Kwieciński et al. 2006), Northern Gannets (Morus bassanus; Votier et al. 2011), and Great Grey Shrikes (Lanius excubitor; Antczak et al. 2010).

The stick nests of Ospreys (Pandion haliaetus) often include both natural items (e.g., wings, bones, dung, and sod) and artificial objects (e.g., clothing, shoes, toys, and rope) (Allen 1892). The propensity of nesting Ospreys for using discarded polypropylene baling twine, which is used by farmers and ranchers to store hay and straw, has recently elicited some conservation concern. For example, all nests near agricultural fields at two study areas in Montana contained twine, which had entangled young in nearly $5 \%$ of nests (Blem et al. 2002). In west-central Saskatchewan, approximately $12 \%$ of nestlings had become entangled (Houston and Scott 2006). Both groups of researchers concluded that entangled nestlings would have died without human intervention. Baling twine hanging from Osprey nests on power poles has come into contact with electrical lines and is thought to have ignited fires, which further endangered nestlings (personal communication with power company linemen).

During visits to Osprey nests in 2012, we noticed that adults had often incorporated baling twine into nests. Various lengths of twine were found in the nest bowl, wrapped around large sticks, or hanging from the nest rim. Three out of $50(6 \%)$ nestlings had become so badly entangled in twine that they had to be rescued, had died, or had to be euthanized (Figure 1). While driving between nests, we often observed remnants of baling twine along the shoulders of secondary roads. The prevalence of plastic string, rope, and twine in the environment surrounding nests has been cited as a reason for their occurrence in nests (Blem et al. 2002; Antczak et al. 2010; Bond et al. 2012), and our observations prompted us to investigate the abundance of discarded baling twine in the landscape surrounding Osprey nests. Our objectives were to estimate and com- 


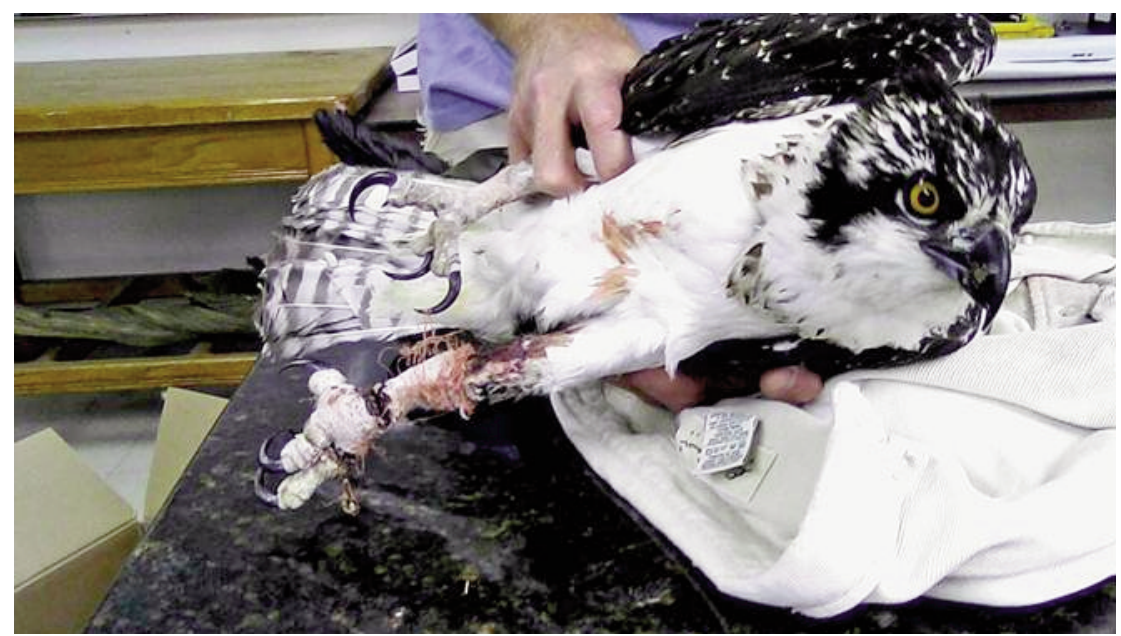

Figure 1. An Osprey (Pandion haliaetus) nestling badly entangled in baling twine and later euthanized, Yellowstone River, Montana, 2012. Compare the normal right foot and tarsus with the grossly swollen and disfigured left foot and tarsus. Photo: Cameron Sapp.

pare the amount of twine along roads near Osprey nests across a gradient from rural to urban landscapes and to assess the relation between the presence of twine in nests and the amount of twine found along roads near nests. Our results have allowed us and our partner, the Yellowstone Valley Audubon Society (YVAS), to target specific areas for cleanup and specific landowners for conservation education.

\section{Study Area}

The study area extended approximately $945 \mathrm{~km}$ along the Yellowstone River floodplain from the Wyoming-Montana border (4459'29"N, 110³0'58"W) to the Montana-North Dakota border $\left(47^{\circ} 45^{\prime} 28^{\prime \prime} \mathrm{N}\right.$, $\left.104^{\circ} 02^{\prime} 42^{\prime \prime} \mathrm{W}\right)$. As the river flows downstream, it changes from a high-gradient, clear, cold mountain system to a low-gradient, turbid, warm-water system. The geomorphology of this dynamic, unregulated river comprises wide multi-channel reaches, forested islands, gravel bars, and straight channels with cliffs. Vegetation along the riparian corridor reflects the decrease in elevation, from higher-elevation $(1750 \mathrm{~m})$ forests dominated by conifers (e.g., Juniperus, Pinus, Picea, and Pseudotsuga spp.) to river bottoms (615 m) composed of a mixture of shrubs (e.g., Salix spp.) and deciduous trees (e.g., Populus spp.). Anthropogenic land uses along the river include small grain farming, livestock grazing, recreation, and urban-centred industries, such as oil refining and coal-fired power generation. Billings (population 106000 ) is the largest city along the river and is situated near the middle of the study area. Climate is semi-arid.

\section{Methods}

Along with 15-20 citizen scientists from YVAS, we conducted fieldwork during the 2012 and 2013 breed- ing seasons. Beginning in April, we used binoculars and spotting scopes to survey the study area for nesting Ospreys. We used a Global Positioning System (GPS; Garmin GPSMAP 62) to record the location of nests and uploaded these coordinates into a geographic information system (GIS). Nests were observed from the ground at approximately 1-week intervals throughout the breeding season to determine occupancy (Steenhof 1987) and to estimate dates of egg laying, hatching, and fledging; brood size; and reproductive success, i.e., number of young fledged (Harmata et al. 2007).

We used ArcGIS (v. 10.1, Environmental Systems Research Institute, Redlands, California, USA) to create a 2-km-radius buffer zone around each of the 71 Osprey nests located in 2012 to identify roads for twine sampling. The size of the buffer zones was large enough to contain an adequate number and length of roads to survey based on our sampling protocol (see below) and small enough to allow us to survey the entire Osprey study population in one season. We obtained a state roads GIS from the Montana Geographic Information Clearinghouse (National Resource Information System 2013*), which categorized roads into seven types: United States Forest Service, primary, secondary, National Highway Administration non-interstate, interstate, city-county, and urban. The roads layer was added to the georeferenced nest buffer zones, and roads were then highlighted and clipped to each buffer zone. Because of safety considerations, we did not survey Interstates 90 or 94 and, therefore, for each buffer zone containing those roads, we subtracted their lengths from the total length of roads. We also omitted six nest buffer zones from further consideration because they contained less than $10 \mathrm{~km}$ of roads, the lower limit of our sampling protocol (see below). We partitioned the remaining 65 nest buffer zones into three road density 
strata based on the total length of roads they contained: low, 10 to $<20 \mathrm{~km}$; moderate, 20 to $<40 \mathrm{~km}$; and high, $\geq 40 \mathrm{~km}$ ). These categories spanned a gradient from agricultural land (rural) to cities (urban) across the heterogeneous study area.

We did not have any a priori information (e.g., variation in metres of twine per buffer zone) to guide sampling effort or allocate kilometres of road per stratum to survey for baling twine, which are required for Neyman-like optimization (Cochran 1977). Therefore, we used square-root of stratum size (i.e., total kilometres of road within each stratum) as a reasonable compromise between equal and proportional allocation of sampling effort (Bankier 1988). The allocated kilometres of road to survey for twine in each nest buffer zone (i.e., sampling effort) increased with road density stratum: low $(10-12 \mathrm{~km})$, moderate $(14-16 \mathrm{~km})$, and high $(\geq$ $18 \mathrm{~km})$. When the buffer zones of different nests overlapped by $\geq 20 \%$, we randomly selected one zone to sample for baling twine, and then, in the field, we did not survey any road segments in the overlapping area to maintain statistical independence in analyses.

In the field during the 2013 nesting season, we used an iPad (Apple, A1430) and the ArcMap application to select and number sequentially each $2-\mathrm{km}$ road segment within a nest buffer zone. A coin flip determined whether a particular segment was surveyed for baling twine, a process repeated up to the allocated number of kilometres to be surveyed for each buffer zone depending on its road density (i.e., low: 10 or $12 \mathrm{~km}$, moderate: 14 or $16 \mathrm{~km}$, and high: $\geq 18 \mathrm{~km}$ ). For example, we surveyed either five or six $2-\mathrm{km}$ road segments in each nest buffer zone in the low road density stratum for a total search effort of either 10 or $12 \mathrm{~km}$. In a few instances, we were unable to survey a selected $2-\mathrm{km}$ road segment because access was restricted. Alternative roads were randomly chosen where possible, but when these were unavailable, we reduced the number of kilometres surveyed in that zone. Travelling by bicycle allowed us to look for twine along both sides of selected roads. We collected twine from the road and pavement edge to fencing along the shoulder (about $4 \mathrm{~m}$ in width). Twine was bagged and labelled by nest buffer zone, and its length (to the nearest metre) was estimated with a tape measure in the laboratory.

Data transformations were unsuccessful in achieving normal distributions; thus, we used the KruskalWallis independent samples test to determine whether the number of metres of baling twine collected per kilometre of road differed among the three road density strata (SPSS v. 19.0, IBM, Armonk, New York, USA). We conducted the same test to determine whether the total amount of twine in a buffer zone (i.e., metres of twine collected per kilometer of road multiplied by total kilometres of roads within a buffer zone) differed among road density strata. We used Dunn's test to identify differences in rank among the three road density strata following a significant Kruskal-Wallis test. Al- though Kruskal-Wallis is a ranks (not a means or median) test, we have provided box plots of data distribution to aid interpretation.

In 2013, we noted which Osprey nests contained baling twine during the banding of nestlings or by observation from the ground. We used logistic regression to examine the relationship between estimated total amount of twine in a buffer zone and the presence or absence of twine in the nest. Goodness of fit was evaluated using the Hosmer-Lemeshow test. We also measured the amount of twine (metres) in nests that had either blown down during storms or had been removed by power company personnel. We used linear and non-linear regression models to test for a relationship between the amount of twine in those nests and the amount of twine found along roads in the corresponding buffer zone (per kilometer of road and total). The significance of all statistical tests was accepted at $P<0.05$.

\section{Results}

Together with YVAS volunteers, we surveyed approximately $925 \mathrm{~km}$ of the Yellowstone River for Osprey nests in 2012 and 2013. All nests considered in the baling twine analyses $(n=65)$ were built on artificial structures (i.e., power poles, nest platforms, or bridge spans). Of the buffer zones around these nests, 25 were located in areas of low road density $(10$ to $<20 \mathrm{~km}), 23$ in areas of moderate road density $(20$ to $<40 \mathrm{~km})$, and 17 in areas of high road density ( $\geq 40 \mathrm{~km}$ ). The number of nests available for statistical analysis decreased after we omitted buffer zones that overlapped by $\geq 20 \%$, leaving us with 19,13 , and 6 nests in the low, moderate, and high road density strata, respectively. The mean number of kilometres of roads surveyed for twine in each nest buffer zone varied across road density strata: low, $10.9 \mathrm{~km}$ (SD 0.7, range 10-12); moderate, $13.5 \mathrm{~km}$ (SD 1.2, range 14-16); and high, $21.3 \mathrm{~km}$ (SD 2.9, range 18-28).

The ranks (amount) of baling twine collected per kilometre of road surveyed within nest buffer zones differed among low, moderate, and high road density strata $(H=6.10, \mathrm{df}=2, P=0.047)$; low road density buffer zones had significantly higher ranks than high road density buffer zones (Figure 2A). However, the ranks of estimated total length of twine in buffer zones did not vary with road density $(H=3.12$, df $=2, P=$ 0.210) (Figure 2B). The percentage of Osprey nests containing twine was nearly twice as high in the low $(63.2 \%, 12$ of 19$)$ and moderate $(61.5 \%, 8$ of 13$)$ road density strata as in the high road density stratum $(33.3 \%$, 2 of 6$)$.

The total amount of baling twine estimated within a nest buffer zone did not predict whether a nest contained twine $\left(\chi^{2}=0.36, \mathrm{df}=1, P=0.547\right)$. Although the data fit the logistic regression model, only 23 of 38 nests $(60.5 \%)$ were classified correctly; all but one contained twine. We observed $93.7 \%$ more nests without 

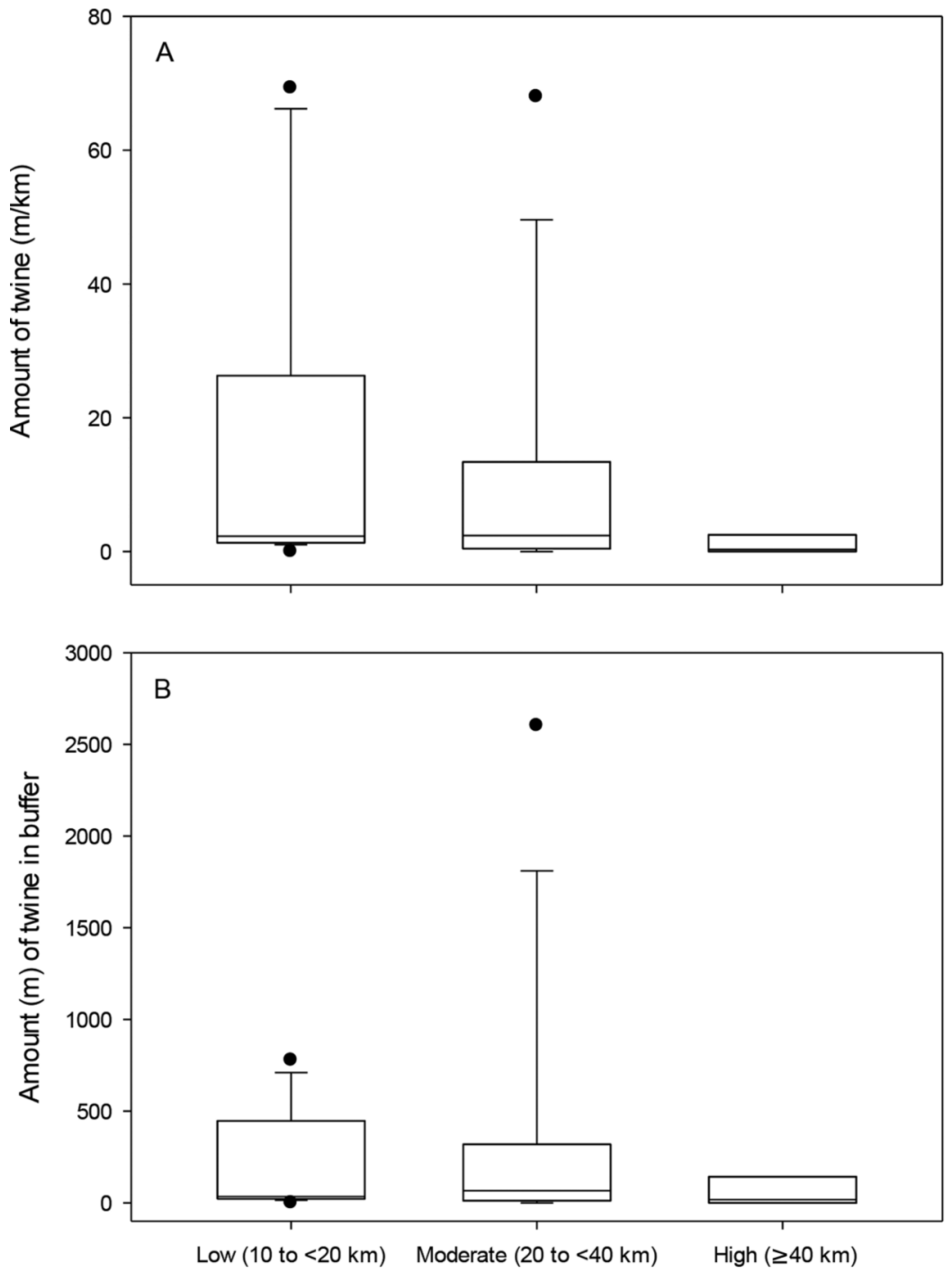

Road density within nest buffer

FIgURE 2. Amount of baling twine in 2-km-radius buffer zones around Osprey (Pandion haliaetus) nests along the Yellowstone River, Montana, 2013. A: Metres of twine per kilometre of road; B: Estimated amount of twine (m) in buffer zones. Note: lines indicate median, boxes show the 25 th and 75 th percentiles, whiskers indicate the 10th and 90th percentiles, and dots show outliers.

twine (15 of 16 nests) than predicted by the model. We collected twine from seven nests that had either blown down in storms or were removed by power company personnel before or after the nesting season in 2013 (Table 1). No relationship existed between the amount of twine found in nests and either the amount of twine found per kilometre of road (linear: $F=1.01, \mathrm{df}=1$, $P=0.362$; non-linear: $F=1.03, \mathrm{df}=1, P=0.357$ ) or the total amount estimated in nest buffer zones (linear: $F=1.05, \mathrm{df}=1, P=0.353$; non-linear: $F=1.09, \mathrm{df}=1$, $P=0.354)$.
Ospreys occupied 28 nests in 2012 and 50 nests in 2013; the large increase in the number of occupied nests located in 2013 reflects the greater field effort on the part of the citizen scientists. Ospreys fledged an average of 1.8 nestlings per occupied nest in 2012 and 1.4 nestlings per occupied nest in 2013. During 2012 , two of $21(9.5 \%)$ successful nests contained three nestlings entangled in twine: one was found dead during the banding visit, one had to be euthanized, and one was cut free and appeared to fledge normally (three of 50 [6.0\%] nestlings entangled). During 2013, one 
TABLE 1. Amount of baling twine found in Osprey (Pandion haliaetus) nests blown down during storms or removed by power company personnel and the estimated amount of twine in a 2-km-radius buffer zone around each nest, Yellowstone River, Montana, 2013.

\begin{tabular}{lccc}
\hline \hline & \multicolumn{3}{c}{ Length of twine, $\mathrm{m}$} \\
\cline { 2 - 4 } Nest ID no. & In nest & $\begin{array}{c}\text { Per km of road } \\
\text { in buffer zone }\end{array}$ & In buffer zone \\
\hline 137 & 0 & 0.2 & 5 \\
295 & 1 & 3.4 & 63 \\
318 & 1 & 1.8 & 22 \\
350 & 206 & 2.2 & 43 \\
354 & 0 & 2.3 & 52 \\
374 & 131 & 26.3 & 447 \\
598 & 64 & 4.3 & 74 \\
\hline \hline
\end{tabular}

of $35(2.9 \%)$ successful nests contained an entangled nestling; it was cut free and appeared to fledge normally (one of $70[1.4 \%]$ entangled nestlings).

\section{Discussion}

We found significantly more baling twine per kilometre of road in Osprey nest buffer zones in low and moderate road density areas than in high road density areas, which reflected the gradient from rural and suburban to urban landscapes. Although we did not find a direct relationship between the estimated total amount of twine in a buffer zone and its presence in nests, the percentage of nests containing twine was highest in rural and suburban areas and lowest in urban areas. The amount of twine found along roads surrounding nests varied considerably: rural buffer zones, $0-778 \mathrm{~m}$; suburban buffer zones, 0-2602 m; and urban buffer zones, 0-506 m.

From our observations in 2012, we knew that baling twine accumulated along roads, and this prompted us to initiate this study, the first to estimate twine abundance near Osprey nests. Surveying roads was convenient and efficient. We believe that measuring the amount of twine found along roads near nests underestimated its abundance in the landscape, because adjacent pastures and feedlots often contained discarded twine. An untested assumption of our study was that a positive relationship exists between the amount of twine along roads and the amount of twine in the 2$\mathrm{km}$-radius buffer zones around nests.

Most farmers and ranchers on our study area store hay and straw in large, round bales, each of which is a potential source of twine for nest-building Ospreys. A single bale contains approximately $115 \mathrm{~m}$ of twine (Houston and Scott 2006). One hay bale can feed one horse or steer per month during winter; therefore, five horses fed for five months require approximately 25 bales (and $2875 \mathrm{~m}$ of twine). It remains unclear how twine is transferred from pastures and feedlots to roads, but we suspect that most had blown off the flat beds of ranch pickup trucks, where we often observed it loosely coiled or piled. In fact, we observed one such instance while conducting twine surveys. Regardless of the mechanism, Ospreys in southern Montana encounter an abundant and apparently available resource for use as nesting material.

Without human intervention, $3.3 \%$ of Osprey nestlings on the Yellowstone River would have died from twine entanglement, which is lower than the $11.7 \%$ nestling mortality reported by Houston and Scott (2006) in Saskatchewan. In our study, the percentage of successful nests in which young were entangled (5.4\%) was higher than that reported from nearby central Montana (4.6\%; Blem et al. 2002). Current estimates of mortality resulting from entanglement on the Yellowstone River does not appear to be of conservation concern regarding the potential for additive mortality because the Osprey population had reproductive rates in 2012 and 2013 greater than those needed to support a stable population (Henny and Wight 1969; Postupalsky 1989). However, twine entanglements did raise animal welfare concerns because nestlings and adults suffered slow deaths from starvation, constriction, and infection. The only practical, short-term solution strategy to prevent deaths from entanglements is to have citizen citizen-scientist volunteers regularly visit nests and contact us if they observed entangled nestlings. In each such instance, power company cooperators have responded quickly to our requests for assistance.

The amount of baling twine we collected from seven nests that had been destroyed by wind or removed by power company personnel varied by two orders of magnitude (0-206 m per nest). Similar variation was reported in the mass of plastics found in five nests constructed by Northern Gannets (Votier et al. 2011). Several proximate factors have contributed to the extent that artificial materials are used in nest construction or as nest adornments: abundance in the environment (Blem et al. 2002; Bond et al. 2012), age of the nest (Votier et al. 2011; Bond et al. 2012), and age of the nest builder (Sergio et al. 2011). On the Yellowstone River, no relationship existed between the amount of twine found in the landscape and the amount found in Osprey nests. We lacked information on the age of nests, but it appeared that larger nests, which were presumably older, contained more twine; however, the limited sample of seven nests made this inference tentative. Although we found a variety of anthropogenic materials in nests, the largest component was baling twine, and such selectivity has been noted in a diversity of bird species from seabirds to raptors to passerines (e.g., Antczak et al. 2010; Sergio et al. 2011; Votier et al. 2011; Bond et al. 2012). Whereas the cost of using baling twine in Osprey nests was clear, any potential benefits have yet to be determined (e.g., conspecific signaling; Sergio et al. 2011).

Educating the public about the risks that baling twine presents to nesting Ospreys is a component of our research project. Together with our partner, YVAS, we mail informational brochures to landowners along the 
Yellowstone River, with the hope of promoting responsible handling and disposal of twine. We are also identifying what we believe are significant sources of the twine that ends up along roads (e.g., feedlots). Polypropylene baling twine degrades slowly and clean-up efforts along roads and in pastures and feedlots will have to be coordinated for decades to reduce dangers to Ospreys (see also Ryan et al. 2009; Bond et al. 2012). It appears that farmers and ranchers are slowly switching from using twine to bale hay and straw to using plastic netting or wraps. We rarely find the latter materials in nests and view such a transition as a potential long-term solution benefitting Ospreys.

\section{Acknowledgements}

This project was a cooperative effort between the Yellowstone River Research Center (Rocky Mountain College) and the Yellowstone Valley Audubon Society. We thank C. Sapp and the dozens of citizen scientists who dedicated countless hours in the field to monitoring nests in 2012 and 2013. W. Newton, statistician at the Northern Prairie Wildlife Research Center (United States Geological Survey), kindly volunteered his time and expertise to design the twine sampling protocol. $\mathrm{He}, \mathrm{A}$. Harmata (Montana State University) and two anonymous reviewers provided valuable comments on the draft manuscript. Generous in-kind support was provided by Beartooth Electric Cooperative, MontanaDakota Utilities, NorthWestern Energy, Park Electric Cooperative, Yellowstone Valley Electric Cooperative, and Yellowstone Valley Tree Surgeons. Many landowners, the United States Bureau of Land Management, the city of Billings, and the Audubon Education and Conservation Center graciously granted permission to monitor and access nests on their properties. This research was approved by the Institutional Animal Care and Use Committee at Montana Fish, Wildlife and Parks (IACUC FWP07-2012) and through a Montana Scientific Collector's Permit (2013-031) to K. Ostovar and a Federal Bird Banding Permit (22513) to M. Restani. Funding was provided by the Yellowstone River Research Center, Toyota TogetherGreen, The Cinnabar Foundation, The Peregrine Fund, Yellowstone Valley Audubon Society, Montana Audubon, Rocky Mountain College, St. Cloud State University, and Montana Fish, Wildlife and Parks.

Documents Cited (marked * in text)

National Resource Information System. 2013. Montana geographic information clearinghouse. Montana State Library, Bozeman, Montana, USA. Accessed 15 October 2013. http://nris.mt.gov/gis/default.asp.

\section{Literature Cited}

Allen, C. S. 1892. Breeding habits of the Fish Hawk on Plum Island, New York. Auk 9: 313-321.
Antczak, M., M. Hromada, P. Czechowski, J. Tabor, P. Zablocki, J. Grzybek, and P. Tryjanowski. 2010. A new material for old solutions - the case of plastic string used in Great Grey Shrike nests. Acta Ethologica 13: 87-91.

Bankier, M. D. 1988. Power allocations: determining sample sizes for subnational areas. The American Statistician 42: 174-177.

Blem, C. R., L. B. Blem, and P. J. Harmata. 2002. Twine causes significant mortality in nestling Ospreys. Wilson Bulletin 114: 528-529.

Bond, A. L., W. A. Montevecchi, N. Guse, P. M. Regular, S. Garthe, and J.-F. Rail. 2012. Prevalence and composition of fishing gear debris in the nests of Northern Gannets (Morus bassanus) are related to fishing effort. Marine Pollution Bulletin 64: 907-911.

Cochran, W. G. 1977. Sampling Techniques. Third Edition. John Wiley and Sons, New York, New York, USA.

Hansell, M. 2000. Bird Nests and Construction Behavior. Cambridge University Press, Cambridge.

Harmata, P. J., M. Restani, and A. R. Harmata. 2007. Settlement patterns, foraging behavior, and reproductive success of Ospreys along a heterogeneous riverine corridor. Canadian Journal of Zoology 85: 56-62.

Henny, C. J., and H. M. Wight. 1969. An endangered Osprey population: estimates of mortality and production. Auk 86 : 188-198.

Houston, C. S., and F. Scott. 2006. Entanglement threatens Ospreys at Saskatchewan nests. Journal of Raptor Research 40: 226-228.

Kwieciński, Z., H. Kwieciński, P. Botko, A. Wysocki, L. Jerzak, and P. Tryjanowski. 2006. Plastic strings as the cause of leg bone degeneration in the White Stork (Ciconia ciconia). Pages 431-436 in White Stork study in Poland: biology, ecology and conservation. Edited by P. Tryjanowski, T. H. Sparks, and L. Jerzak. Bogucki Wydawnictwo Naukowe, Pozńan.

Montevecchi, W. A. 1991. Incidence and types of plastic in gannets' nests in the northwest Atlantic. Canadian Journal Zoology 69: 295-297.

Postupalsky, S. 1989. Osprey. Pages 297-313 in Lifetime reproduction in birds. Edited by I. Newton. Academic Press, London.

Ryan, P. G., C. J. Moore, J. A. van Franeker, and C. L. Moloney. 2009. Monitoring the abundance of plastic debris in the marine environment. Philosophical Transactions of the Royal Society B 364: 1999-2012.

Sergio, F., J. Blas, G. Blanco, A. Tanferna, L. Lopez, J. A. Lemus, and F. Hiraldo. 2011. Raptor nest decorations are a reliable threat against conspecifics. Science 331: 327-330.

Steenhof, K. 1987. Assessing raptor reproductive success and productivity. Pages 157-170 in Raptor Management Techniques Manual. Edited by B. A. Giron Pendleton, B. A. Millsap, K. W. Cline, and D. M. Bird. National Wildlife Federation, Washington, D. C., USA.

Votier, S. C., K. Archibald, G. Morgan, and L. Morgan. 2011. The use of plastic debris as nesting material by a colonial seabird and associated entanglement mortality. Marine Pollution Bulletin 62: 168-172.

Received 7 December 2013

Accepted 31 January 2014 